\title{
The Impacts of Consumer Ethnocentrism on Foreign Product Judgment and Local Helping Purchase: A Case of Malaysian Cross-Border Shoppers in Hatyai, Thailand
}

\author{
Wanwisa Kuncharin ${ }^{1} \&$ Badaruddin Mohamed $^{1}$ \\ ${ }^{1}$ School of Housing, Building and Planning, Universiti Sains Malaysia, Malaysia \\ Correspondence: Wanwisa Kuncharin, School of Housing, Building and Planning, Universiti Sains Malaysia, \\ Malaysia. Tel: 1-6401-5109.E-mail: sattaro_bobby@hotmail.com
}

Received: December 30, 2013

Accepted: July 3, $2014 \quad$ Online Published: August 22, 2014

doi:10.5539/ijbm.v9n9p135

URL: http://dx.doi.org/10.5539/ijbm.v9n9p135

\begin{abstract}
Cross-border shopping is the phenomenon when consumers travel to an adjacent country for the specific purpose of purchasing products or services and purchasing activities that can be made during a business or tourist visit. It is also viewed as a subcategory of tourism and leisure. Hatyai, Thailand is located around $30 \mathrm{~km}$ from the Malaysian border. The statistics reports that each year more than 400,000 Malaysian visitors visited Hatyai, Thailand. This study aims to investigate the impact of consumer ethnocentrism on foreign product judgment and local helping purchase. The data were collected through self-administered questionnaires among a sample of 423 Malaysian tourists who have done some shopping in Hatyai, Thailand. The results revealed that consumer ethnocentrism have a significant negative impact on foreign product judgment, while consumer ethnocentrism has a significant positive impact on local helping purchase. The result from this study would be helpful in designing and improving effective marketing strategies and conducting marketing campaigns for retailers and tourism marketers on both sides of the border while satisfying the needs of the shoppers.
\end{abstract}

Keywords: consumer ethnocentrism, foreign product judgment, local helping purchase, cross-border shoppers

\section{Introduction}

Cross-border shopping is the phenomenon when consumers travel to an adjacent country for the specific purpose of purchasing products or services and purchasing activities that can be made during a business or tourist visit (Euromonitor, 2004; Dmitrovic \& Vida, 2007; Lau et al., 2005; Mogab et al., 2005). According to the definition as given by Timothy (2000), a tourist is someone who crosses a political boundary, either international or subnational. Thus, cross-border shopping is also viewed as a subcategory of tourism and leisure. Cross-border shoppers are tourists who cross another country's border for the purpose of shopping. Traditional definitions of international tourists are normally defined with an element of temporary travel, which involves crossing an international border, and often includes pleasure as a purpose of the trip (Ganster \& Lorey, 2005). Jarratt (1998) supported that during these trips to a neighbouring country, cross-border shoppers may participate in other activities such as going to the movies, visiting a museum and an historic or natural attraction, eating in a restaurant, and staying in local accommodations. Some authors elaborated that cross-border shopping is the purchase and the consumption that take place in border areas beyond one's own national state border, regardless of whether the products are bought and consumed on the other side, or are brought back to the home country, and it includes a broad range of products and services (Follo, 2003; Kim \& Sullivan, 2003; Nijssen \& Herk, 2009).

Timothy \& Butler (1995) worked out a model to represent the general pattern of cross-border shopping (Figure 1); the more distant shoppers live from the border, the less frequent will they cross the borders to shop. Nevertheless, the value of the items they buy would probably be higher. Residents of the proximal shopping zone generally cross the border more often and are willing to go every day, and they probably purchase small-ticket items like gasoline, groceries, beer, tobacco products, and restaurant meals. Residents of the medial shopping zone cross the border less often and they tend to buy higher-value goods. Residents of the distal shopping zone (the people who live farthest from the borders) seldom cross the border for shopping, but when they do, they tend to purchase big-ticket items like clothes, appliances, and electronics. 


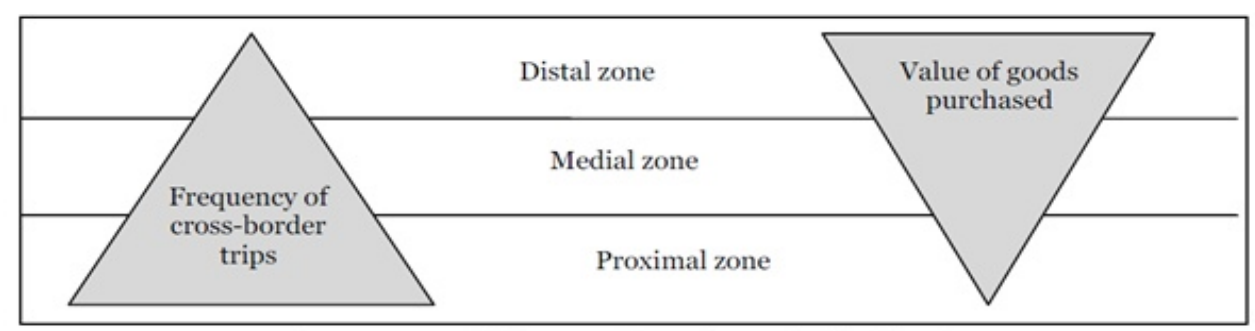

Figure 1. Spatial characteristics of cross-border shopping

With growing globalization, consumer cross-border shopping into an adjacent country is increasing around the world in many countries such as between the United States and Mexico (Brodowsky \& Beverlee, 2003; Goh et al., 2007; Guo \& Wang, 2009; Sullivan, 2008), the United States and Canada (Di Matteo \& Di Matteo, 1996; Papadopoulos, 1980; Sullivan and Klang, 1997), Denmark and Germany (Bygvra, 1998), Norway and Sweden (Follo, 2003; Karlsson \& Lindgren, 2010), Singapore and Malaysia (Hui \& Wan, 2008; Piron, 2002; Tansuhaj et al., 1989), Brunei and Malaysia (Anaman \& Ismail, 2002; Subramaniam et al., 2008), and Hong Kong and Shenzhen, China (Ju, 2010; Lau et al., 2005; Wang, 2004).

Cross-border shoppers can be viewed as consumers when they do shopping in a neighbouring country. Consumer ethnocentrism refers to a consumer who has the tendency to purchase locally instead of to purchase aboard. Therefore, ethnocentricism affects one's tendency to cross the border to shop. A highly ethnocentric shopper might not outshop at all because she/he feels that it would hurt the domestic economy, it would cause loss of jobs, and it would be unpatriotic (Shimp \& Sharma, 1987). The increase in cross-border shopping also results from the growth in international travel and consumer awareness of foreign cultures and their products or services (Nijssen \& Herk, 2009). Less ethnocentric consumers often travel and make purchases abroad (Dmitrovic \& Vida, 2007; Nijssen \& Herk, 2009; Piron, 2002). This has resulted in greater interest in examining consumer ethnocentric tendencies (Nijssen \& Herk, 2009), and consumer attitudes towards products of different countries (Nijssen \& Susan, 2004). Moreover, consumers' bias towards their national products is a significant determinant of local product purchase behaviour (Josiassen, 2011). Consumer ethnocentrism has been found to be negatively related to foreign product judgments (Klein et al., 1998; Netemeyer et al., 1991; Nijssen \& Douglas, 2004), and positively related to local helping purchase (Balabanis \& Diamantopoulos, 2004; Dmitrovic \& Vida, 2009).

In consequence, examining consumer ethnocentric tendencies can help marketers to conduct effective marketing strategies. In fact, local and global marketers need to consider the level of consumer ethnocentrism among consumers before launching their products in foreign countries (Phau \& Chan, 2003). Moreover, exploring consumers' attitudes towards domestic and foreign products can help local and global marketers to conduct more effective local and global marketing strategies (Cheron \& Hayashi, 2001).

Hatyai is located in Songkhla Province (Figure 2), the largest city in Southern Thailand and populated by nearly 800,000 Thais. The residents of Hatyai are a mix of Thais, Chinese, and Muslims. Hatyai is located 950 kilometers from Bangkok and 30 kilometers from the Malaysian border (Bukit Kayu Hitam-Sadao Border). Hatyai is a commercial, shopping, and entertainment centre. There are at least six large shopping malls including Lee Garden Plaza, Odean Shopping Mall, Diana Shopping Mall, and Central Department Store, as well as Tesco Lotus and Carrefour superstores (Figure 2). Furthermore, there are various kinds of street-side vendors and stalls found in the two main markets. Consequently, it is a popular destination for visitors from Malaysia. The statistics reports that each year more than 400,000 Malaysian visited Hatyai because the value of Thai baht is lower compared with the Malaysian currency. Thus, Malaysian residents cross the border to buy goods and services at cheaper prices. In 2011 alone, 631,345 Malaysian tourists visited Hatyai, whereas in 2010 there were only 431,056 tourists from Malaysia (Department of Tourism of Thailand, 2012). 


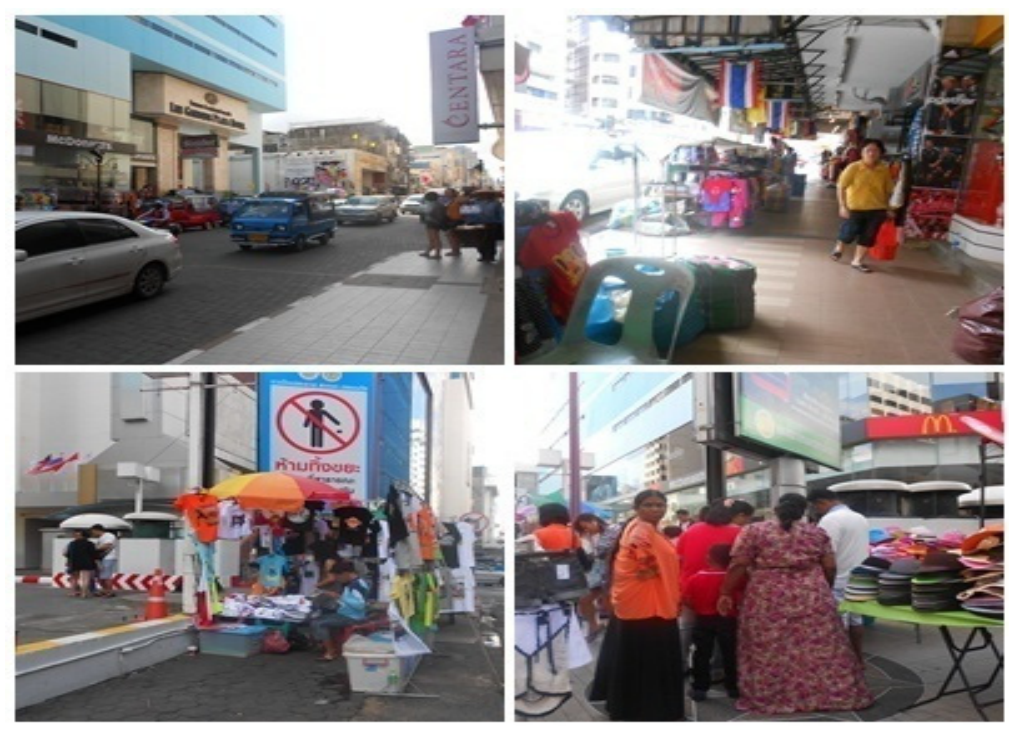

Figure 2. Shopping destinations in Hatyai, Thailand

This study has two objectives: (1) to investigate the impact of consumer ethnocentrism on foreign product judgment; and (2) to investigate the impact of consumer ethnocentrism on local helping purchase.

\section{Conceptual Background and Hypothesis Development}

\subsection{Cross-Border Shopping}

Many researchers defined outshopping as the purchase of goods by consumers outside their local shopping areas (Blakney \& Sekely, 1994; Hawes \& Lumpkin, 1984; Jaratt, 2000; Papadopoulos, 1980; Polonsky \& Jarratt, 1991). Sullivan \& Savitt (1997) also supported this by saying that outshopping happens when consumers leave their local community to purchase goods or services. Guo \& Wang (2009) identified outshopping as shopping outside one's local community for various reasons such as to obtain better quality merchandise at relatively competitive price points and pleasant shopping environment. A broad definition of outshopping would include those of some authors, such as Tansuhaj et al. (1989), Piron (2002), Wang et al. (2010), as they defined international outshopping as consumers purchasing away from their home country and that they identified shopping as a motivation for going aboard. Cross-border shopping occurs when consumers travel outside their local area and cross a national boundary outside their local area into an adjacent country primarily to shop (Dmitrovic \& Vida, 2007; Lau et al., 2005; Mogab et al., 2005). Thus, cross-border shopping is regarded as a subcategory of international outshopping and outshopping (Figure 3), where shoppers travel out of their town to a neighbouring country for shopping of goods and services (Lau et al., 2005)

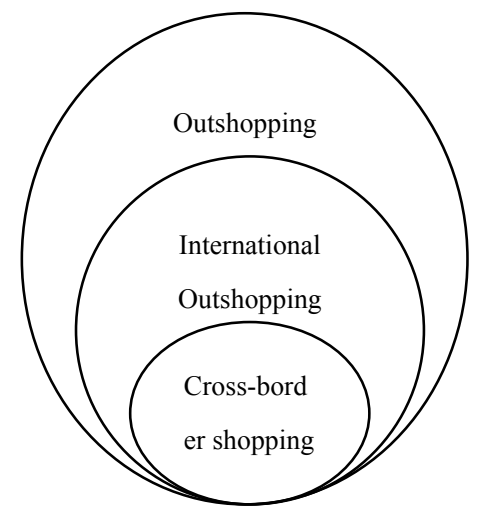

Figure 3. Relationships between cross-border shopping, international outshopping and outshopping 


\subsection{Consumer Ethnocentrism}

Marketers and retailers often study consumer ethnocentrism to develop strategic marketing plans for entering into new foreign markets. They do this to understand the attitudes and beliefs of the foreign consumers. The concept ethnocentrism was first introduced by Sumner (1906) who explained it as the tendency to regard one own's beliefs, standards and code of behaviour as superior to those of other societies. Shimp \& Sharma (1987) defined consumer ethnocentrism as the concept to represent consumers' beliefs in the superiority of their own countries' products. From the perspective of ethnocentric consumers, purchasing imported products is wrong because in their minds, it hurts the domestic economy, it causes loss of jobs, and it is plainly unpatriotic. Products from other countries are objects of contempt to highly ethnocentric consumers. In addition, the consumers with higher level of consumer ethnocentrism have better attitude towards domestic products. Sharma et al. (1995) noted that consumer ethnocentricity is expected to have a strong impact on attitudes towards importing products. To nonethnocentric consumers, foreign products are objects to be evaluated on their own merits without considering where they are made. This moral aspect causes consumer to purchase domestic products, even though in extreme cases, the quality is below that of the imports (Sinkovics \& Hartmut, 1994).

The measurement of consumer ethnocentrism was made with the development of The CETSCALE (Consumer Ethnocentric Tendencies Scale) by Shimp \& Sharma (1987). The CETSCALE comprises 17 items which measure the attitude of consumer towards foreign and domestic products. The CETSCALE (17 items) is a tool to measure the level of ethnocentricity. Since the introduction of the CETSCALE, researchers all over the world are using this construct measurement to understand the effect of consumer ethnocentrism on the attitudes of consumers towards local and foreign made products (Khairul \& Ibrahim, 2012). Previous research regarding cross-border shopping and consumer ethnocentrism (e.g., Piron, 2002; Timothy, 1999) cited that cross-border shoppers exhibit a low level of ethnocentrism, indicating a lesser tendency to view shopping and buying products from overseas instead of at home as inappropriate behaviour. Piron (2002) found that low ethnocentric cross-border shoppers usually travel and do shopping abroad.

\subsection{Relationship between Consumer Ethnocentrism and Foreign Product Judgement}

A foreign product judgement refers to a consumer's attitude towards foreign products in general and the interaction of quality judgements based on country of origin and and attitudes towards foreign products in general (Klein et al., 1998). The increase in cross-border shopping results because of customers' awareness about foreign products (Nijssen \& Douglas, 2004). The purchase of foreign products may even be seen as simply unpatriotic (Klein, 2002; Netemeyer et al., 1991; Sharma et al., 1995; Shimp \& Sharma, 1987). Klein et al. (1998) hypothesized that feelings of highly ethnocentric consumers would affect consumers' purchasing behaviour towards foreign products. They concluded that ethnocentric tendencies are significantly negatively correlated with attitudes towards foreign products. Klein (2002) elaborated that those who believe that it was wrong to buy foreign products or that only domestic products should be purchased, also tend to denigrate the quality of foreign products. According to Figure 4, previous studies found that consumer ethnocentrism has been found to be negatively related to product judgements (Klein et al., 1998; Netemeyer et al., 1991; Klein et al., 1998; Shimp \& Sharma, 1987). This proposition is summarized in the following hypothesis:

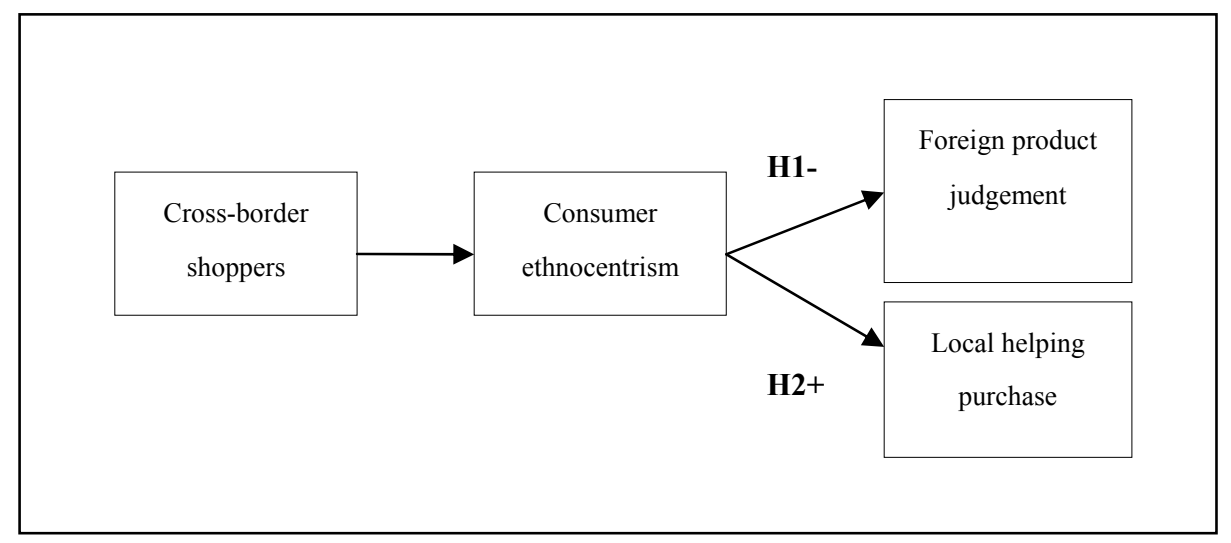

Figure 4. Conceptual framework 
H1: Consumer ethnocentrism has a negative impact on foreign product judgments.

\subsection{Relationship between Consumer Ethnocentrism and Local Helping Purchase}

Consumer ethnocentrism refers to consumers' judgements of the morality of purchasing foreign made products. Consumer ethnocentrism has been found to relate positively to consumer preference for domestic products, and negatively to preference for foreign products (Shimp \& Sharma, 1987). Granzin \& Olsen (1988) developed a concept of local helping purchase behaviour. They defined local helping purchase as an individual's purchase-related behaviour in support of the domestic economy. They examined purchasing domestic products on the behaviour of American consumers and concluded that buying local products by American consumers had negative relationship with helping costs and positive relationship with responsibility. Dmitrovic \& Vida (2007) summarized that the local helping purchase behaviour was operationalized as purchase-related behaviour at the levels of

- seeking products of both domestic branding and domestic manufacture;

- looking at labels to identify these products; and

- shopping at retail stores that sell domestic products.

By choosing domestic over foreign products or brands, consumers support the domestic economy (Granzin \& Olsen, 1998). Balabanis \& Diamantopoulos (2004) also confirmed that ethnocentricity better explains positive consumer attitudes towards domestic products than the negative attitude towards foreign products. As previous studies have concluded that there is a tendency for consumers to evaluate their own country's products more favourably than products bought from foreign countries (Balabanis et al., 2001; Balabanis \& Diamantopoulos, 2004). Dmitrovic \& Vida (2007) explored cross-border shopping behaviour in South-East Europe and found that local helping purchase was found to be highly significant predictors of cross-border shopping behaviour. Cross-border shoppers who have high level of local helping purchase tend to shop less in aboard. Dmitrovic \& Vida (2009) studied the impact of consumer ethnocentrism on local helping purchase in four countries of the South-East Europe (Croatia, Bosnia and Herzegovina, Serbia, and Montenegro). The results for all four country samples indicated that consumer ethnocentrism was positively related to local helping purchase (Figure 4). Based on the theoretical backgrounds presented earlier, the following hypothesis is proposed:

H2: Consumer ethnocentrism has a positive impact on local helping purchase.

\section{Research Method}

\subsection{Instrument Development}

Data were collected using self-administrative questionnaire (Bygvra, 1998; Wang, 2004; Yeung \& Yee, 2011). The questionnaire was developed in English and was translated into Malay and Chinese by language translators and then native Malay and Chinese speaker, also fluent in English, retranslated it back into English to ensure consistency (Cha et al., 2007). Prior to the survey, a pilot test was conducted with 20 respondents who were randomly selected. Apparently, the respondents were able to understand and to answer the questions, and therefore, only few minor changes were made to the questionnaire for clarity. The questionnaire comprised the following major sections:

The first part contained pertaining to samples' sociodemographic variables (age, gender, ethnicity, highest educational level, occupation, marital status, average income per month).

- Consumer ethnocentrism (10 items) was modified from the original CETSCALE by Shimp \& Sharma (1987). Each scale in this section was measured by a 5 -point Likert scale $(1=$ strongly disagree to $5=$ strongly agree).

- Foreign product judgements (4 items) were specifically adapted from Klein et al. (1998). Components in this section were measured on a 5 -point Likert scale $(1=$ strongly disagree to $5=$ strongly agree $)$.

- Local helping purchase (6 items) was adapted from Granzin \& Olsen (1998). The questions in this section were measured by using a 5 -point Likert scale $(1=$ strongly disagree to $5=$ strongly agree $)$.

\subsection{Reliability of Data}

To establish the reliability of this study measurement used in the survey instrument, the reliability coefficient (Cronbach alpha) was verified. The constructs in the measurement had the estimated reliability-coefficient of 0.938 from 10 consumer ethnocentrism items, 0.703 from four foreign product judgment items and 0.895 for six local helping purchase items. The minimum value for accepting the reliability test is 0.7 (Nunnally, 1978). According to this rule, all of the constructs in the measurement of this study thus fulfilled this requirement. 


\subsection{Data Collection}

The target population of this study was defined as Malaysian citizens (age over 18), they all stayed in Hatyai for at least one night and have done some shopping during their trip. Moreover, they were willing to fill the questionnaires. The data was gathered by using the questionnaires with 460 visitors in Hatyai with tourists from Malaysia. The questionnaires were distributed daily from 9.30 a.m to 9.30 p.m for 3 months from January March, 2013. A total of 460 respondents was recruited in various shopping outlets located at Hatyai, Thailand. The samples were selected using the mall-intercept technique on a face-to-face base (Yeung \& Yee, 2012). The respondents were approached by the researchers and another four trained surveyors, who understood fully the issues regarding to the survey. The questionnaires were filled by the respondents themselves, if the respondents were unable to complete the questionnaires; they were requested to return them personally the following day to the interviewers at the selected shopping outlets.

\section{Results}

Out of 460 questionnaires, 423 questionnaires were usable (92\% response rate). Unusable questionnaires included missing in some sections and uncompleted questionnaires.

\subsection{Demographic Characteristic Profile of Respondents}

As Table 1 displays, $61 \%$ of the respondents were female while $39 \%$ were male. Most of the respondents were under the age group between $25-35$ years old (34.5\%), and followed by $27.9 \%$ from the age group between 36-45 years old. The other proportion of the respondents was between the ages grouping of 45-60 years old (17.5\%). Majority of the respondents were Chinese (37.6), followed by Malays (37.4\%), Indians which accounted $19.9 \%$. In terms of education level, more than half of the respondents $(50.6 \%)$ are university graduated. Most of the visitors were private employees (29.6\%), while $29.3 \%$ were vendor or businessperson and $17.7 \%$ were working as government employees. More than half $(56.7 \%)$ of the respondents were married, while $35.5 \%$ of the respondents were single. Almost $50.1 \%$ of the respondents come from the Northern part of Malaysia, due to the fact that, the northern region of Malaysia is bordered by Thailand. Followed by $19.1 \%$ of the respondents come from Central part and $12.1 \%$ come from Southern part. Approximately $43.7 \%$ of the respondents had income between RM1,000 and RM 2,999 per month, which was about the medium level. About $25.5 \%$ of the respondents had income higher than the medium level (RM 3,000 to RM 4,999). While $14.9 \%$ of the respondents had income higher than RM7,000.

Table 1. Demographic characteristic profile of respondents $(n=423)$

\begin{tabular}{llcc}
\hline & Demographic characteristics & Frequency & Percent \\
& & & $\%$ \\
\hline \multirow{2}{*}{ Gender } & Male & 165 & 39.0 \\
& Female & 258 & 61.0 \\
\hline Age & $18-24$ & 68 & 16.1 \\
& $25-35$ & 146 & 34.5 \\
& $36-45$ & 118 & 27.9 \\
& $45-60$ & 74 & 17.5 \\
& $\geq 61$ & 17 & 4.0 \\
\hline Ethnicity & Malays & 158 & 37.4 \\
& Chinese & 159 & 37.6 \\
& Indians & 84 & 19.9 \\
& Others & 22 & 5.2 \\
\hline Highest education & Non Degree/Primary school/ Secondary School & 101 & 23.9 \\
& Diploma & 108 & 25.5 \\
& University Graduated & 214 & 50.6 \\
\hline Occupation & Government Employee & 75 & 17.7 \\
& Private Employee & 125 & 29.6 \\
& Labor, Farmer & 44 & 10.4 \\
& Vendor/ Businessperson & 124 & 29.3 \\
& Student & 32 & 7.6 \\
& Unemployed/Housewives/Retired & 23 & 5.4 \\
\hline \multirow{2}{*}{ Marital status } & Single & 150 & 35.5 \\
\hline
\end{tabular}




\begin{tabular}{llcc}
\hline & Married & 240 & 56.7 \\
& Divorced & 24 & 5.7 \\
& Widowed & 9 & 2.1 \\
\hline \multirow{2}{*}{ Area lived in Malaysia (State) } & North & 212 & 50.1 \\
& South & 51 & 12.1 \\
& East Coast & 49 & 11.6 \\
& Central & 81 & 19.1 \\
& Sabah Sarawak, Labuan & 30 & 7.1 \\
\hline Average income per month & Below RM1,000 & 40 & 9.5 \\
& RM1,000 to RM2,999 & 185 & 43.7 \\
& RM3,000 to RM4,999 & 108 & 25.5 \\
& RM5,000 to RM6,999 & 27 & 6.4 \\
& RM7,000 and above & 63 & 14.9 \\
\hline
\end{tabular}

\subsection{The Impact of Consumer Ethnocentrism on Foreign Product Judgment}

Simple linear regression will be used to achieve research objective one; to investigate the impact of consumer ethnocentrism on foreign product judgment. The goal in regression analysis is to create a mathematical model that can be used to predict the values of a dependent variable based upon the values of an independent variable. In this study, consumer ethnocentrism was identified as the independent variable and foreign product judgment was indicated as the dependent variable. According to Table 2, the analysis suggests that consumer ethnocentrism explain only $0.066(\mathrm{R}$ Square $=0.066$ ) of foreign product judgments. The $\beta$ coefficient was -0.257 , $\mathrm{t}$-value was -5.463 and significant p-value was 0.000 , which was lower than 0.05 . It shows that the consumer ethnocentrism has impact on foreign product judgments.

Table 2. Simple linear regression of consumer ethnocentrism on foreign product judgments

\begin{tabular}{|c|c|c|c|c|c|}
\hline \multirow[t]{2}{*}{ Model } & \multicolumn{2}{|c|}{ Unstandardized coefficients } & $\begin{array}{c}\text { Standardized } \\
\text { coefficients }\end{array}$ & $\mathrm{t}$ & Sig. \\
\hline & B & Std. Error & Beta & & \\
\hline Shopper ethnocentrism & -0.158 & 0.029 & -0.257 & -5.463 & $0.000 * *$ \\
\hline
\end{tabular}

Note. R Square $=0.066 ;$ Adjusted R Square $=0.064$; Model statistics: $\mathrm{F}=29.840 ;{ }^{*} \mathrm{p}<0.05,{ }^{* *} \mathrm{p}<0.01$;

Independent variable: consumer ethnocentrism; Dependent variable: foreign product judgment.

In order to test hypothesis one (H1), consumer ethnocentrism has a negative impact on foreign products judgments. Pearson correlation is performed to test the correlation between consumer ethnocentrism, and foreign product judgments (See Table 3). Based on the Pearson values, there is a significant negative correlation between consumer ethnocentrism, and foreign product judgment ( $\mathrm{p}$-value $=0.000$, Pearson correlation $=-0.340$ ) at 0.01 . This can be explained that when the level of consumer ethnocentrism increased then the level of foreign product judgment also decreased. Hence, hypothesis one (H1) was supported. The finding was in agreement with existing research; in another study of Malaysian consumers, Khairul \& Ibrahim (2012) studied consumer ethnocentric tendencies of Malaysian Muslim consumers and cited that the level of consumer ethnocentric tendencies among Malaysian Muslim consumers would had a negative relationship with the judgment of US made product.

Table 3. Pearson correlation coefficients between consumer ethnocentrism and foreign product judgments

\begin{tabular}{clc}
\hline \multicolumn{1}{c}{ Variables } & \multicolumn{1}{c}{ Statistic } & Foreign product judgments \\
\hline Consumer ethnocentrism & Correlation coefficient & $-0.340^{* *}$ \\
& Sig. (2-tailed) & 0.000. \\
Note. & N*. Correlation is significant at the 0.01 level (2-tailed) & 423 \\
\hline
\end{tabular}




\subsection{The Impact of Consumer Ethnocentrism on Local Helping Purchase}

Simple linear regression analysis was conducted to achieve research objective two; to investigate the impact of consumer ethnocentrism on local helping purchase. Results from Table 4 shows that consumer ethnocentrism (The $\beta$ coefficient was 0.371 , $t$-value was 8.206 ) significantly affected local helping purchase $(F=67.344, p$ value $=0.00$ ). The analysis indicated that there was a significant model which had fit the data, about $13.8 \%$ of variance in local helping purchase was explained by consumer ethnocentrism. Hence, it indicated that the consumer ethnocentrism had impact on local helping purchase.

Table 4. Simple linear regression of consumer ethnocentrism on local helping purchase

\begin{tabular}{lccccc}
\hline Model & \multicolumn{2}{c}{$\begin{array}{c}\text { Unstandardized } \\
\text { coefficients }\end{array}$} & $\begin{array}{c}\text { Standardized } \\
\text { coefficients }\end{array}$ & t & Sig. \\
\cline { 2 - 5 } & B & Std. Error & Beta & & \\
\cline { 2 - 5 } Shopper ethnocentrism & 0.420 & 0.051 & 0.371 & 8.206 & $0.000^{* * *}$ \\
\hline
\end{tabular}

Note. R Square =0.138; Adjusted R Square =0.136; Model statistics: $\mathrm{F}=67.344 ;{ }^{*} \mathrm{p}<0.05, * * \mathrm{p}<0.01$.

Independent variable: consumer ethnocentrism; Dependent variable: local helping purchase.

Pearson correlation was performed to test hypothesis two (H2); consumer ethnocentrism has a positive impact on local helping purchase. According to Table 5, the correlation coefficient between consumer ethnocentrism and local helping purchase was significant positive but medium relation at 0.01 ( $\mathrm{p}$ value $=0.000$, Pearson correlation $=0.371$ ). Cohen (1988) suggests that there is considered medium correlation if the correlation coefficient value is between 0.30 to 0.49 and -0.3 to- 0.49 . In other word, when the level of consumer ethnocentrism increased, the level of local helping purchase also increased. Thus, hypothesis two (H2) was supported. The finding was in line with Durvasula et al. (1997) found that ethnocentric individuals have a strong positive attitude towards their own country. Consumer ethnocentrism has been found to be positively related to local helping purchase (Balabanis \& Diamantopoulos, 2004; Dmitrovic \& Vida, 2009).

Table 5. Pearson correlation coefficients between consumer ethnocentrism and local helping purchase

\begin{tabular}{llc}
\hline \multicolumn{1}{c}{ Variables } & Statistic & Local helping purchase \\
\hline Consumer ethnocentrism & Correlation coefficient & $0.371^{* *}$ \\
\hline Sig. (2-tailed) & 0.000 \\
\hline N & 423 \\
\hline ** Correlation is significant at the 0.01 level (2-tailed).
\end{tabular}

\section{Conclusions and Recommendations}

Based on the finding of this study, consumer ethnocentrism was found to have a negative impact on foreign product judgments. A possible explanation was when the level of consumer ethnocentrism increased, the level of foreign product judgments also decreased. The finding was in agreement with other studies had found that generally, consumers who had high level of ethnocentrism would negatively evaluate foreign made products (Shimp \& Sharma, 1987; Kaynak \& Kara, 2002), especially in the developed country. Shimp \& Sharma (1987) cited that the ethnocentric group might believe that it was not appropriate or immoral to buy foreign products or services. As a result, the contribution of this study was to help the retailers and tourism marketers in Thailand to make appropriate marketing strategies and marketing campaign. Lantz \& Loeb (1996) recommend foreign products should be priced slightly lower than local products, if the type of products or services are similar, to capture the less ethnocentric segment of the market. Then the marketing strategies by retailers and tourism marketers in Thailand should focus on the lower price of products, services, transportation and other expenditures in order to attract less ethnocentric cross-border shoppers to cross the border to shop. In addition, in order to control the impact of shopper ethnocentrism on foreign product judgments and do "outshopping" in aboard, tourism marketers may conduct marketing campaign by placing a greater emphasis on Thailand destination's image as well as brand image of products and services from Thailand to occupy the less ethnocentric segment of the market. 
The result found that consumer ethnocentrism had a positive impact on local helping purchase. It can be explained that when the level of consumer ethnocentrism increased, the level of local helping purchase also increased. This is further supported by Dmitrovic \& Vida (2007), cross-border shoppers who exhibited higher level of local helping purchase tended to shop less in foreign countries. Therefore, in order to attract less ethnocentric segment of the market to do "inshopping", the marketing campaign by local Malaysian tourism marketers could include the best approached using pro-Malaysian image to promote the benefits of local products or services and local shopping destination. Moreover, in order to prevent retail leakages and attract shoppers to do "inshopping", the marketing strategies by retailers in Malaysia should try to create a belief that their products and services are value for money.

\subsection{Recommendations for Future Research}

As this study examined only one single market, next researchers may conduct a comparative study of the impact of Thai cross-border shopper ethnocentrism on foreign product judgments and local helping purchase for comparison. In addition, it is also recommended that future research on cross-border consumer ethnocentrism and attitude towards foreign product and local helping purchase behaviour should be conducted in other regions for comparison. Lastly, the primary limitations of this study also provide a basis for future research, need to be mentioned. Data for the present study was collected exclusively in the shopping destinations in Hatyai. Hence, the results are not to be generalised to the entire population with various cross-border shopping destinations in Thailand. Results should also be generalized with caution to overall cross-border shopping destinations in Thailand. Moreover, consumer ethnocentrism, foreign product judgments and local helping purchased selected in this study could be a limitation because other variables, which were not used in this study, could affect cross-border shopping behaviour.

\section{References}

Anaman, K. A., \& Ismail, R. A. (2002). Cross-border tourism from Brunei Darussalam to Eastern Malaysia: an empirical analysis. Singapore Economic Review, 47, 65-87.

Balabanis, G., \& Diamantopoulos, A. (2004). Domestic country bias, country-of-origin effects, and consumer ethnocentrism: a multidimensional unfolding approach. Journal of the Academy of Marketing Science, 32, 80-95. http://dx.doi.org/ 10.1177/0092070303257644

Balabanis, G., Diamantopoulos, A., Mueller, R. D., \& Melewar, T. C. (2001). Impact of nationalism, patriotism, and internationalism on consumer ethnocentric tendencies. Journal of International Business Studies, 32(1), 157-175. http://dx.doi.org/10.1057/palgrave.jibs. 8490943

Blakney, V. L., \& Sekely, W. (1994). Retail attributes: influence on shopping mode choice behavior. Journal of Managerial Issues, 6(1), 101-119.

Bygvra, S. (1998). The road to the single European market as seen through the Danish retail trade: cross-border shopping between Denmark and Germany. The International Review of Retail, Distribution and Consumer Research, 8, 147-164. http://dx.doi.org/ 10.1080/09593969800000003

Bygvra, S. (1999). Retail trade at European borders: A pilot study. Proceeding of 11th international conference on research in the distributive trades (pp. 484-493).

Cha, E. S., Kim, K. H., \& Erlen, J. A. (2007). Translation of scales in cross-cultural research: issues and techniques. Journal of Advanced Nursing, 58, 386-395.

Cheron, E., \& Hayashi, H. (2001). The Eeffect of respondents' nationality and familiarity of product attributes in consumer choice: globalization and the evaluation of domestic and foreign products. Japanese Psychological Research, 43(4), 183-194. http://dx.doi.org/ 10.1111/1468-5884.00176

Department of Tourism of Thailand. (2012). Tourism Statistics: International tourist arrival to Hadyai, Thailand. Retrieved June 19, 2013, from http://www.tourism.go.th/2010/th/statistic/tourism.php?cid=30

Di Matteo, L., \& Di Matteo, R. (1996). An analysis of Canadian cross-border travel. Annals of Tourism Research, 23(1), 103-122. http://dx.doi.org/ 10.1016/0160-7383(95)00038-0

Dmitrovic, T., \& Vida, I. (2004, June). Cross-border shopping behavior in former Yugoslav markets. Proceeding of 2nd international conference, an enterprise Odyssey: building competitive advantage, Zagreb, Croatia.

Dmitrovic, T., \& Vida, I., (2007). An examination of cross-border shopping behaviour in South-East Europe. European Journal of Marketing, 41(3-4), 382-395. http://dx.doi.org/ 10.1108/03090560710728390

Dmitrovic, T., \& Vida, I. (2009). The role of product nationality in purchase behavior. Economic Research, 2(2). 
Durvasula, S., Andrews, J., \& Netemeyer, R. (1997). A cross-cultural comparison of consumer ethnocentrism in the United States and Russia. Journal of International Consumer Marketing, 9(4), 73-93. http://dx.doi.org/10.1300/J046v09n04_05

Euromonitor. (2004). Qualitative study on cross-border shopping in 28 European countries. Retrieved on February 18, 2013, from http://ec.europa.eu/public_opinion/quali/q1_cbs2004_en.pdf

Follo, G. (2003). Borderline-land: Norwegian cross border shopping between purchase and Trip. Working Paper 3/05, Centre for Rural Research, Norwegian University of Science and Technology, Norway.

Ganster, P., \& Lorey, D. (2005). Borders: border politics in a globalizing world. New York: SR Books.

Goh, B., Fowler, D., Lauderdale, M., \& Yuan, J. (2007, November). Mexicans shopping in the United States: an economic force in Texas. Proceeding of Society for Marketing Advances Conference, Sheraton Gunter Hotel, San Antonio, Texas, the United States.

Granzin, K. L., \& Olsen, J. E. (1998). Americans' choice of domestic over foreign products: a matter of helping behavior? Journal of Business Research, 43, 39-54. http://dx.doi.org/ 10.1016/S0148-2963(97)00101-X

Guo, C., Vasquez-Parraga, A., \& Wang, Y. (2006). An exploratory study of motives for Mexican nationals to shop in the U.S.: More than meets the eye. Journal of Retailing and Consumer Services, 13(5), 351-362. http://dx.doi.org/10.1016/j.jretconser.2005.11.002

Hawes, J., \& Lumpkin, J. R. (1984). Understanding the outshopper. Journal of the Academy of Marketing Science, 12(4), 200-218. http://dx.doi.org/ 10.1177/009207038401200414

Hui, T. K., \& Wan, D. (2008). The cross-border shopper's behavior: the case of Singapore. International Journal of Data Analysis Techniques and Strategies, 1(1), 104-115. http://dx.doi.org/10.1504/IJDATS.2008.020025

Jarratt, D. G. (1998). Modeling out-shopping behaviour: a non-metropolitan perspective. The International Review of Retail. Distribution and Consumer Research, 8(3), 319-350. http://dx.doi.org/10.1080/095939698342805

Jarratt, D. G. (2000). Outshopping behaviour: an explanation of behaviour by shopper segment using structural equation modeling. The International Review of Retail, Distribution and Consumer Research, 10(3), 287-304. http://dx.doi.org/ 10.1080/095939600405983

Josiassen, A., Assaf, A. G., \& Karpen, I. O. (2011). Consumer ethnocentrism and willingness to buy: Analyzing the role of three demographic consumer characteristics. International Marketing Review, 28(6), 627-646. http://dx.doi.org/ 10.1108/02651331111181448

$\mathrm{Ju}$, P. (2010). Research on the characteristics of spatial behavior of Hong Kong cross-border consumer. Prodeeding of international conference on e-business, management and economics, Hong Kong.

Karlsson, S., \& Lindgren, U. (2010, August). From manufacturing to retail: cross-border shopping and economic restructuring in West Sweden. Paper presented at 50th Anniversary European Congress of the Regional Science Association International "Sustainable Regional Growth and Development in the Creative Knowledge Economy, Jonkoping, Sweden.

Kaynak, E., \& Kara, A. (2002). Consumer perceptions of foreign products: an analysis of product-country images and ethnocentrism. European Journal of Marketing, 36(7-8), 928-949. http://dx.doi.org/10.1108/03090560210430881

Khairul, A. M. S., \& Ibrahim, H. I. (2012). Consumer ethnocentrism: does it really matter for Malaysian consumers. West East Journal of Social Sciences, 1(1), 26-38.

Kim, E. Y., \& Sullivan, P. (2003). Cross-border tourism and shopping: consumer segmentation. E-Review of Tourism Research, 1(1).

Klein, J. G. (2002). Us versus them, or US versus everyone? delineating consumer aversion to foreign goods. Journal of International Business Studies, 33(2), 345-363.

Klein, J. G., Ettenson, R., \& Morris, M. D. (1998). The animosity model of foreign product purchase: an empirical test in the People's Republic of China. Journal of Marketing, 62(1), 89-100.

Lantz, G., \& Loeb, S. (1996). Country of origin and ethnocentrism: an analysis of Canadian and American preferences using social identity theory. Advances in Consumer Research, 23, 374-378.

Lau, H., Sin, L., \& Chan, K. (2005). Chinese cross-border shopping: an empirical study. Journal of Hospitality and Tourism Research, 29(1), 110-33. http://dx.doi.org/10.1177/1096348004272178 
Mogab, J. W., Pisani, M. J., McGlashan, N. K., Welkey, S., \& Wuest, B. E. (2005). Manifiesto: The Texas sales tax rebate and cross-border Mexican shoppers. Texas Business Review, 1-5.

Netemeyer, R. G., Durvasula, S., \& Lichtenstein, D. R. (1991). A cross-national assessment of the reliability and validity of the CETSCALE. Journal of Marketing Research, 28(3), 320-327. http://dx.doi.org/10.2307/3172867

Nijssen E. J., \& Susan, P. D. (2004). Examining the animosity model in a country with a high level of foreign trade. International Journal of Research in Marketing, 21(1), 23-38. http://dx.doi.org/10.1016/j.jiresmar.2003.05.001

Nijssen, E. J, \& Herk, H. (2009). Conjoining international marketing and relationship marketing: exploring consumers' cross-border service relationships. Journal of International Marketing, 17(1), 91-115. http://dx.doi.org/10.1509/jimk.17.1.91

Nijssen, E. J., \& Douglas, S. (2004). Examining the animosity model in a country with a high level of foreign trade. International Journal of Research in Marketing, 21, 23-38. http://dx.doi.org/10.1016/j.jiresmar.2003.05.001

Nunnally, J. C. (1978). Psychometric theory (2nd ed.). New York: McGraw-Hill.

Papadopoulos, N. G. (1980). Consumer out-shopping research: review and extension. Journal of Retailing, 56.

Phau, L., \& Chan, K. W. (2003). Targeting east Asian markets: a comparative study on national identity. Journal of Targeting, Measurement and Analysis for Marketing, 12(2), 157-172.

Piron, F. (2002). International outshopping and ethnocentrism. European Journal of Marketing, 36(1-2), 189-210. http://dx.doi.org/10.1108/03090560210412755

Polonsky, M, J., \& Jarratt, D. G. (1991). Rural outshopping in Australia: the Bathurst-Orange region. European Journal of Marketing, 26(10), 5-11. http://dx.doi.org/10.1108/EUM0000000000647

Sharma, T. A., Shimp, S. S., \& Shin, J. (1995). Consumer ethnocentrism: A test of antecedents and moderators. Journal of the Academy of Marketing Science, 23(1), 26-37.

Shimp, T. A., \& Sharma, S. S. (1987). Consumer ethnocentrism: construction and validation of the CETSCALE. Journal of Marketing Research, 24(3), 280-289.

Sinkovics, R., \& Hartmut, H. (1994). Ethnocentrism: a key determinant in international corporate strategy formulation. Paper Presented at EIBA International Conference, Warsaw. Retrieved May 11, 2012, from http://wwwen.ac.at/marketing

Subramaniam, T., Devadason, E., \& Sundararaja, S. (2008). Cross-Border shopping behaviour of Bruneians in Limbang, Sarawak: A preliminary analysis. Borneo Research Journal, 2.

Sullivan, P. M. (2008). How the open Mexican border helps U.S. retailers: happy holiday season 2008 at destination outlet malls in Texas. Research Review, 16(2), 13-17.

Sullivan, P. M., \& Kang, J. (1997). Information sources and motivational attributes of Canadian cross-border shoppers: A pilot study. International Journal of Commerce and Management, 7(1), 88-107. http://dx.doi.org/10.1108/eb047345

Sullivan, P. M., \& Savitt, R. (1997). Store patronage and lifestyle factors: implications for rural grocery retailers. International Journal of Retail \& Distribution Management, 25(11), 351-364. http://dx.doi.org/10.1108/09590559710192459

Sumner, W. G. (1906). Folkways. Boston: Ginn and Company.

Tansuhaj, P., Ong, W. C., \& McCullough, J. (1989). International outshoppers: what are they like. Singapore Marketing Review, 4, 93-97.

Timothy, D. J. (1999). Cross-border shopping: tourism in the Canada-United States borderlands. Visions in Leisure and Business, 17(4), 4-18.

Timothy, D. J. (2000). Borderlands: an unlikely tourist destination? Boundary and Security Bulletin, 8(1), 57-65.

Timothy, D. J., \& Butler, R. W. (1995). Cross-border shopping: a North American perspective. Annals of Tourism Research, 22(1), 16-34. http://dx.doi.org/10.1016/0160-7383(94)00052-T

Wang, D. (2004). Hong Kongers' cross-border consumption and shopping in Shenzhen: patterns and motivations. Journal of Retailing and Consumer Services, 11, 149-159. 
http://dx.doi.org/10.1016/S0969-6989(03)00014-6

Wang, Y. J., Doss, S. K., Guo, C., \& Li, W. (2010). An investigation of Chinese consumers' outshopping motives from a culture perspective: implications for retail and distribution. International Journal of Retail \& Distribution Management, 38(6), 423-442. http://dx.doi.org/ 10.1108/09590551011045375

Yeung, R. M. W., \& Yee, W. M. S. (2011, July). Cross-border shopping: stimulant factors for crossing from China to Macao. Proceedings of the Academy of Marketing Conference 2011: Marketing Field Forever, Academy of Marketing, Liverpool, UK.

Yeung, R. M. W., \& Yee, W. M. S. (2012). A profile of the mainland Chinese cross-border shoppers: cluster and discriminant analysis. Tourism Management Perspectives, 4, 106-112. http://dx.doi.org/10.1016/j.tmp.2012.06.001

\section{Copyrights}

Copyright for this article is retained by the author(s), with first publication rights granted to the journal.

This is an open-access article distributed under the terms and conditions of the Creative Commons Attribution license (http://creativecommons.org/licenses/by/3.0/). 